\title{
IMPACT OF SUNFLOWER SEEDS AND/OR VITAMIN E AND SELENIUM SUPPLEMENTATION ON MILK COMPOSITION AND FATTY ACIDS PROFILE OF LACTATING BALADI GOATS
}

\author{
Wafaa M.A. Ghoneem \\ Animal Production Department, Faculty of Agriculture, Cairo University, Giza 12613, Egypt.
}

(Received 15/2/2016, accepted 10/3/2016)

\section{SUMMARY}

$\mathrm{T}$ wenty eight lactating Baladi goats (3-4 years old and the average weight ranged from 33.9 $35.6 \mathrm{~kg}$ ) after two weeks of parturition were assigned according to milk production into four groups (7 animals each). Each group was randomly assigned to feed one of the following experimental rations, control ration (R1) consists of 50\% concentrate feed mixture and 50\% Egyptian clover (Trifolium alexandrinum), control ration was supplemented with either whole sunflower seeds (SFS) to provide 3.5\% oil from DM intake (R2), $250 \mathrm{IU}$ vitamin E and $2 \mathrm{mg}$ selenium/h/d (R3) or both of the previous supplementation (R4). There were no significant differences among tested groups in digestibility of DM, CP, $\mathrm{CF}$ and EE. The lowest nutrients digestibility was recorded with R2 while, the highest were with R4. Goats fed either R3 or R4 had the highest globulin and the lowest cholesterol concentrations in blood plasma. There were no differences among groups in DMI, milk yield and milk contents of protein, lactose, TS and SNF while, milk fat content was increased with SFS supplementation (R2 and R4) compared with R1. Feeding on rations supplemented with vitamin E plus selenium (R3 and R4) increased their concentrations in milk. Total saturated fatty acids were decreased and total unsaturated fatty acids (TUFA), mono- and poly- unsaturated fatty acids were increased in milk when goats fed on R2 and R4. It could be concluded that feeding lactating goats on ration supplemented with SFS and vitamin E plus selenium improved lactation performance and increased TUFA, vitamin E and selenium in milk, which may have good impact on consumer's health.

Keywords: Sunflower seeds, vitamin E, selenium, goats, milk composition and fatty acids profile.

\section{INTRODUCTION}

Recently, there is a growing interest among the consumers related to health considerations to consume high-quality, safe and nutritious foods which is known by functional food (Pizzoferrato et al., 2007 and Kralik et al., 2012). Doyon and Labrecque (2008) defined functional food as" the food that fortified, enriched or enhanced foods with a component having a health benefit beyond basic nutrition can be considered, or it is the food components that may have health benefits that reduce the risk of specific diseases or other health concerns".

Whole sunflower seeds (SFS) contains one of the most healthy vegetable oils because it is rich in polyunsaturated FA (PUFA) especially, linoleic acid (66\% of total FA), which is an n-6 FA (Petit et al., 2004 and Ebrahimi et al., 2014). Also, Morsy et al. (2015) reported that SFS have no anti-nutritional factors compared with the other oilseeds such as rapeseeds, soybeans and cottonseeds. So, it can be used safely as a feed ingredient in animal rations. Ebrahimi et al. (2014) found that feeding on SFS resulted in an increase of conjugated linoleic acid, CLA, and omega- 6 content in milk and meat of ruminant animals. Also, increases in milk production and milk composition as fat content, CLA and omega 3 were recorded when lactating goats fed on 50g SFS /h/d (Morsy et al., 2015). Abd El-Nabi (2012) showed that the highest FCM and CLA contents were recorded with lactating goats fed SFS to provide ration by $3.5 \%$ oil compared with soybean seeds and linseeds. Zucali et al. (2007) observed a decrease in medium and short chain fatty acids (C8-C16) content and an increase in long chain fatty acids content when SFS was added to lactation Alpine goats' diet by 5-6\%.

Vitamin E (Vit E) is considered as an antioxidant that reduces free radicals, mono-unsaturated fats and saturated fats which help in reducing cholesterol level (Zanetti et al., 2015). Also, the essential trace mineral, selenium (Se), has high importance to human health due to its role in immune system activation and reduction the risk of cardiovascular disease and cancer (Margaret, 2000). Bayril et al. (2015) found that supplementation with Se and Vit E increased milk yield and decreased incidence of sub-clinical 


\section{Ghoneem}

mastitis. In the same trend, Zanetti et al. (2015) indicated that either steers fed ration supplemented with Se or people consumed the steers' meat had higher Se and lower cholesterol concentrations in serum.

This study aimed to investigate the effect of supplementing sunflower seeds and/or vitamin E and selenium to lactating goat rations on milk production, milk composition, vitamin $\mathrm{E}$ and selenium levels and fatty acids profile of milk.

\section{MATERIALS AND METHODS}

This work was carried out at Agricultural Experimental Station, Sheep and Goat Research Unit, Faculty of Agriculture, Cairo University, Giza, Egypt.

\section{Experimental animals and rations:}

Twenty eight lactating Baladi goats (3-4 years old and the average weight ranged from $33.9-35.6 \mathrm{~kg}$ ) after two weeks of parturition were assigned into four groups of 7 animals each according to milk production. The experimental period was 36 days (30 days for adaptation and 6 days for samples collection). Each group was randomly assigned to feed one of the following experimental rations, control ration (R1) consists of 50\% concentrate feed mixture and 50\% Egyptian clover (Trifolium alexandrinum), control ration was supplemented with either whole sunflower seeds to provide $3.5 \%$ oil (R2), 250 IU vitamin E and $2 \mathrm{mg}$ selenium/h/d (R3) or both of the previous supplementations (R4).

Rations were offered by $4 \%$ of body weight calculated to cover total nutrient requirements for lactating goats according to NRC (1981). The concentrate feed mixture was consisted of $60 \%$ yellow corn, $10 \%$ soybean meal, $10 \%$ sunflower meal, $15 \%$ wheat bran, , $1.2 \%$ premix, $0.8 \%$ common salt and $3 \%$ limestone. Vitamin E product (DSM rovemix E50) contained 500.000 IU tocopheryl acetate $/ \mathrm{kg}$ was added to provide the ration with $250 \mathrm{IU}$ vitamin E/h/d. Selenium (SEL-PLEX ${ }^{\mathrm{TM}}$ ) is selenium (Se)enriched yeast which contained $1000 \mathrm{ppm} \mathrm{Se} / \mathrm{kg}$ was added to provide the ration with $2 \mathrm{mg} \mathrm{Se} / \mathrm{h} / \mathrm{d}$.

\section{Digestibility trial:}

A grab sample method was applied at which acid insoluble ash (AIA) was used as an internal marker according to Van-Keulen and Young (1977) for determining nutrients digestibility. Fecal grab samples were collected for three successive days at the end of the lactation trial from each animal. Feed consumption and residues were recorded daily. Nutrients digestibility were calculated according to the following formula:

$$
\text { Digestion coefficient }=100-\left[100 \times \frac{96 \text { idicator in feed }}{96 \text { indicator in feces }} \times \frac{96 \text { nutrient in feces }}{\text { g6 nutrient in feed }}\right]
$$

\section{Milk sampling:}

Kids were removed for $12 \mathrm{~h}$ (from $7 \mathrm{pm}$ to $7 \mathrm{am}$ ) during three successive days at the end of adaptation period, then goats were hand-milked, the estimated milk yield was multiplied by two to estimate the daily milk production according to Smeti et al. (2014). One tenth of the milk yields for each animal as milk samples was immediately collected after milking, then samples were stored at $\left(-18^{\circ} \mathrm{C}\right)$ for further analysis. After taking milk samples, kids were suckled the remaining milk.

\section{Feces sampling:}

Fecal samples were collected once daily at 7.00 am for three successive days from each goat. Subsample $(10 \%)$ of the total collected feces was sprayed with $10 \%$ sulfuric acid and then dried at $60^{\circ} \mathrm{C}$ for 24 hour. Dried feces were kept individually in polyethylene bags for chemical analysis.

\section{Blood sampling:}

At the last day of the experimental period, blood samples were withdrawn individually from the jugular vein $4 \mathrm{hrs}$ after the morning meal in tubes contained anticoagulant agent (EDTA). Collected blood samples were centrifuged at 4000 r.p.m for 20 minutes and blood plasma kept at deep freeze $\left(-18^{\circ} \mathrm{C}\right)$ for further analysis. 


\section{Analytical procedures:}

\section{Feeds and feces analysis:}

Chemical analyses of feedstuffs and feces samples were carried out according to the methods of AOAC (2012). The nitrogen free extract (NFE) was calculated by difference.

\section{Blood plasma analysis:}

Blood plasma total protein and creatinine were measured as described by Tietz (1990). Blood plasma albumin was determined according to Doumas et al. (1971). Alanin amino transferase (ALT) and aspartate amino transfearse (AST) were determined according to Young (1990). Blood plasma cholesterol was determined according to Flegg (1973).

\section{Milk analysis:}

Milk samples were analyzed for total solids, fat, protein and lactose by infrared spectrophotometery (Foss matic 120 Milko- Scan, Foss Q3 183 Electric, Hillerød, Denmark) according to AOAC (1995) procedure. Solids not fat content of milk was calculated by the difference between total solids and fat content. Fatty acids profile of milk was determined via gas liquid chromatography (GLC) according to Farag et al. (1986). Vitamin E and selenium were analyzed at the regional center for food and feed (Giza, Egypt). Vitamin E was determined according to Danish official (1996). Selenium was determined in the form of selenium dioxide by atomic absorption spectrometry as described by Muniz-Naveiro et al. (2005).

\section{Statistical analysis:}

Data were analyzed by the least squares procedure of the General Linear Models Program of SAS (2009) according to procedures outlined by Snedecor and Cochran (1982). Data of milk yield, milk composition, nutrients digestibility's and blood plasma parameters were analyzed using one way analysis of variance. The model used was as following:

$$
\mathbf{y}_{\mathrm{ij}}=\mu+\mathrm{T}_{\mathrm{i}}+\mathbf{e}_{\mathrm{ij}}
$$

Where:

$\mathbf{Y}_{\mathbf{i j}}$ : The $\mathrm{j}^{\text {th }}$ animal of the $\mathrm{i}^{\text {th }}$ treatment.

H: The overall mean.

$\mathrm{T}_{\mathrm{i}}$ : The fixed effect of the $\mathrm{i}^{\text {th }}$ treatment.

$\mathbf{e}_{\mathbf{i j}} \mathbf{j}^{\mathbf{z}}$ The random error assumed to be normally and independently distributed.

The Duncan's New Multiple range test (Duncan, 1955) and Least Square Means, LSM (Steel and Torrie, 1980) procedures were used to test the significance among means for all data $(\mathrm{p}<0.05)$.

\section{RESULTS AND DISCUSSION}

\section{Chemical composition of feed ingredients and experimental rations:}

Data concerning chemical composition of feed ingredients and experimental rations are presented in Table (1). Results indicate that sunflower seeds (SFS) used in this study had lower EE content (39.52\%) and higher CF content (25.37\%) compared with data obtained by Abd El-Nabi (2012) being 44.00 and $22.50 \%$ or those obtained by Morsy et al, (2015) being 40.30 and $22.60 \%$, respectively. While, CP content was almost the same with the other previous studies.

Data in the same Table showed that experimental rations were similar in its chemical composition except those supplemented with SFS (R2 and R4) were higher in CP, CF and EE and lower in NFE contents. These results may be due to high $\mathrm{CP}, \mathrm{CF}$ and $\mathrm{EE}$ and low NFE contents in SFS. These results agreed with the finding of Abd El-Nabi (2012). 
Table (1): Chemical composition of feed ingredients and experimental rations (DM basis).

\begin{tabular}{lccccccc}
\hline \multirow{2}{*}{ Feed } & \multicolumn{7}{c}{ Chemical composition, \% } \\
\cline { 2 - 8 } ingredients & DM & OM & CP & CF & EE & NFE & Ash \\
\hline CFM & 93.77 & 90.03 & 13.25 & 8.10 & 3.81 & 64.87 & 9.97 \\
FC & 17.19 & 89.38 & 14.45 & 29.21 & 2.05 & 43.67 & 10.62 \\
SFS & 92.54 & 96.18 & 20.10 & 25.37 & 39.52 & 11.19 & 3.82 \\
Experimental rations* & & & & & & \\
R1 & 92.12 & 89.73 & 13.80 & 17.82 & 3.00 & 55.11 & 10.27 \\
R2 & 92.15 & 90.23 & 14.36 & 19.20 & 5.90 & 50.77 & 9.77 \\
R3 & 92.12 & 89.73 & 13.80 & 17.81 & 3.00 & 55.12 & 10.27 \\
R4 & 92.15 & 90.23 & 14.36 & 19.20 & 5.90 & 50.77 & 9.77 \\
\hline
\end{tabular}

CFM: Concentrate feed mixture. FC: Fresh clover (Trifolium alexandrinum). SFS: Sunflower seeds

R1: CFM+FC (control). R2: control+SFS. R3: control + vitamin E and selenium. R4: control+SFS+ vitamin E and selenium.

*Calculated

\section{Digestion coefficients and nutritive values:}

Data dealing with digestion coefficients of the experimental rations (Table 2) showed that there was no significant $(\mathrm{P}<0.05)$ difference in DM digestibility (DMD) among control ration $(\mathrm{R} 1)$ and other rations (R2, R3 and R4). The same trend was mentioned by Abd El-Nabi (2012) and Petit et al. (2004) that there was no any significant effect on DMD when SFS supplemented ration fed to goats or dairy cows. While, Beauchemin et al. (2009) recorded a decrease in DMD with SFS supplementation in dairy cows ration. The lowest DMD recorded for R2 could be due to the high EE content as mentioned by Vargas et al. (2011) that rumen fermentation negatively affected by fat inclusion, while Narimani-Rad et al. (2012) reported the opposite with sunflower oil supplementation by in vitro study.

Table (2): Digestion coefficients and nutritive values of the experimental rations.

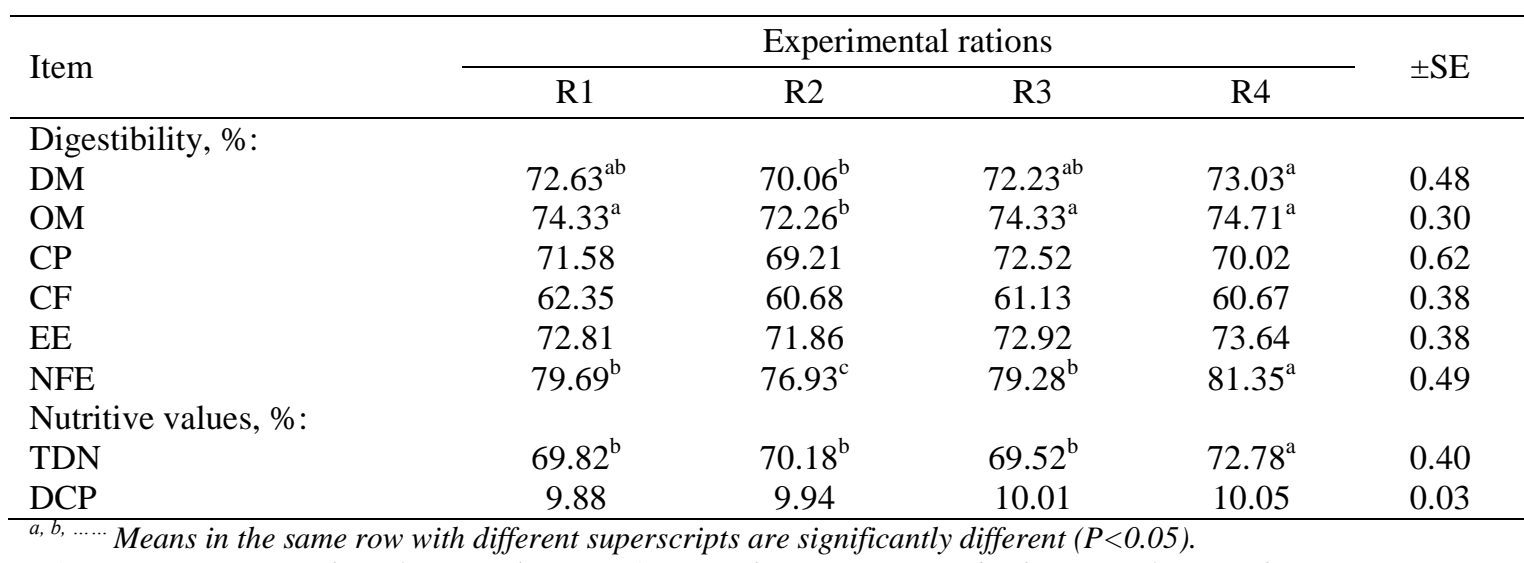

R1: CFM+FC (control). R2: control+SFS. R3: control + vitamin E and selenium. R4: control+SFS+ vitamin E and selenium.

Organic matter digestibility did not significantly $(\mathrm{P}<0.05)$ differ among R1, R3 and R4. While, feeding goats on R2 significantly $(\mathrm{P}<0.05)$ decreased digestibility of OM and NFE by 3.6 and $3.5 \%$, respectively compared with R1. Also, a decrease in OM digestibility was recorded when SFS included in ration by Beauchemin et al. (2009).

There were no significant $(\mathrm{P}<0.05)$ differences among groups in the digestibility of $\mathrm{CP}, \mathrm{CF}$ and $\mathrm{EE}$ being, (71.58, 62.35 and 72.81), (69.21, 60.68 and 71.86), (72.52, 61.13 and 72.92) and (70.02, 60.67 and 73.64), respectively for R1, R2, R3 and R4. These results may be due to the hard seed coat of SFS which protects the internal oil from rumen biohydrogenation and prevents the negative effect of oil on rumen microbes (Ekeren et al., 1992). Jenkins and Palmquist (1982) found that high concentration of unsaturated fatty acids in feed ingredients had less toxic effect on rumen microbes. Feeding goats on R3 didn't significantly $(\mathrm{P}<0.05)$ affect digestibility of NFE while, with R4 it was significantly $(\mathrm{P}<0.05)$ increased 
compared with R1 being, 79.28, 81.35 and 79.69, respectively. Abd El-Nabi (2012) reported that there were no any significant differences in digestibility of EE between control and SFS rations, while CP digestibility was increased with SFS supplementation.

The best nutritive value as TDN was recorded with SFS plus vitamin E and selenium supplementation (R4) was being $72.78 \%$, while there was no significant difference among R2, R3 and control (R1) being $70.18,69.52$ and $69.82 \%$, respectively. The increase in TDN value may be due to the highest digestibility of DM and NFE with R4 compared with the other treatments. However, no significant differences were observed among treatments in DCP value. These results were in agreement with those obtained by Abd El-Nabi (2012).

\section{Blood plasma parameters:}

Data in Table (3) shows that no significant differences were detected among different groups in blood plasma total protein, AST and ALT concentrations. These results are paralleled with Morsy et al. (2015) when goat ration was supplemented with $50 \mathrm{~g} \mathrm{SFS/head/d} \mathrm{and} \mathrm{with} \mathrm{Juniper} \mathrm{et} \mathrm{al.} \mathrm{(2006)} \mathrm{when} \mathrm{added}$ selenized yeast to ration of lactating dairy cows.

Table (3): Effect of experimental rations on blood plasma parameters of lactating Baladi goats.

\begin{tabular}{|c|c|c|c|c|c|}
\hline \multirow{2}{*}{ Parameters } & \multicolumn{4}{|c|}{ Experimental rations } & \multirow{2}{*}{$\pm \mathrm{SE}$} \\
\hline & $\mathrm{R} 1$ & $\mathrm{R} 2$ & R3 & $\mathrm{R} 4$ & \\
\hline Total protein $(\mathrm{g} / \mathrm{dl})$ & 6.27 & 6.00 & 6.47 & 6.53 & 0.10 \\
\hline Albumin $(\mathrm{g} / \mathrm{dl})$ & $3.80^{\mathrm{a}}$ & $3.67^{\mathrm{a}}$ & $2.90^{\mathrm{b}}$ & $2.93^{\mathrm{b}}$ & 0.14 \\
\hline Globulin (g/dl) & $2.47^{\mathrm{b}}$ & $2.33^{\mathrm{b}}$ & $3.57^{\mathrm{a}}$ & $3.60^{\mathrm{a}}$ & 0.18 \\
\hline $\operatorname{AST}(\mathrm{u} / \mathrm{l})$ & 79.75 & 81.58 & 80.67 & 83.00 & 0.65 \\
\hline $\operatorname{ALT}(\mathrm{u} / \mathrm{l})$ & 16.33 & 17.17 & 16.67 & 16.50 & 0.19 \\
\hline Cholesterol $(\mathrm{mg} / \mathrm{dl})$ & $123.03^{\mathrm{a}}$ & $118.40^{\mathrm{b}}$ & $118.07^{\mathrm{b}}$ & $112.83^{\mathrm{c}}$ & 1.19 \\
\hline
\end{tabular}

$\overline{a, b, \ldots . . .}$ Means in the same row with different superscripts are significantly different $(P<0.05)$.

It was indicated that rations supplemented with SFS or vitamin E plus selenium alone or together significantly $(\mathrm{p}<0.05)$ decreased plasma cholesterol level. Same trend was reported by Petit et al. (2004) that insignificant decrease in blood cholesterol level was recorded with SFS supplementation to dairy cows ration and showed that the effect on blood cholesterol could be altered by type of fatty acid. However, Garcia-Bojalil et al. (1998) noted an increase in blood cholesterol by fat supplementation. On the other hand, Morsy et al. (2015) found no change in blood cholesterol level of goats fed SFS supplemented ration.

Blood plasma globulin recorded higher values with R3 and R4 compared with R1 and R2. This result agreed with findings of Latorre et al. (2014) that rations enriched with vitamin E plus selenium and/or canola oil had an important role in increasing immunity and decreasing the susceptibility to infections of bulls. Liu et al. (2008) implied an improvement in antioxidant status due to a synergistic relationship between Vit $\mathrm{E}$ and Se which may be due to their effect in reducing the free radicals (Kim et al., 1997). Latorre et al. (2014) mentioned that fatty acids supplementation could be a method to improve immunity, but depends on type of polyunsaturated F.A contained in ration. Morsy et al. (2015) observed insignificant increase in blood globulin concentration with SFS supplementation.

The present results concerning blood metabolites showed no adverse impact on goats health, since these values of blood parameters are within the normal physiological ranges which reported by Merck (2014).

\section{Milk yield and composition:}

It was observed from Table (4) that there was no difference in dry matter intake (DMI) among experimental groups. Also, Markus et al. (1996) and Petit et al. (2004) recorded the same result with dairy cows or lactating goats (Morsy et al., 2015) fed SFS supplemented ration. While, Dayani et al. (2004) found a decrease in DMI with SFS ration fed to lactating dairy cows. Beauchemin et al. (2009) recorded an increase in DMI with SFS supplementation in lactating dairy cows ration. Pfister et al. (2013) concluded that feed consumption did not change either by sheep or cattle when fresh forages contained high Se concentration. They explained that adjusting the intake of animals should be done to prevent excessive Se intake.

Actual milk and FCM yields were not significantly $(\mathrm{P}<0.05)$ changed among different groups. However, the highest milk and FCM yields recorded with R4 and the lowest values were recorded with 
R2. It could be attributed to with the highest TDN in R4. Zucali et al. (2007) observed a decrease in milk yield when goats fed SFS in semi-intensive production system and Mohammed et al. (2011) showed the same result with dairy cows. Markus et al. (1996) and Dayani et al. (2004) noted no significant differences in milk and FCM yields of dairy cows with SFS ration compared with soybean seeds ration. On the other hand, Abd El-Nabi (2012) and Morsy et al. (2015) found a significant $(\mathrm{P}<0.05)$ increase in milk yield of goats fed SFS ration. Regarding vitamin E and selenium supplementation, there were insignificant $(\mathrm{P}<0.05)$ increases in milk yield and FCM with R3 and R4 compared with R1. This result agreed with findings of Charmley et al. (1993) and Bayril et al. (2015) that a significant increase in milk yield was recorded with Vit E and Se supplementations in lactating dairy cows ration. They noted that might be due to the improvement in udder health by decreasing mastitis incidence or it could be attributed to the decrease in oxidative stress (Lacetera et al., 1996).

Table (4): Effect of experimental rations on dry matter intake, milk yield and composition, concentrations of milk vitamin $E$ and selenium and feed efficiency.

\begin{tabular}{|c|c|c|c|c|c|}
\hline \multirow{2}{*}{ Item } & \multicolumn{4}{|c|}{ Experimental rations } & \multirow{2}{*}{$\pm \mathrm{SE}$} \\
\hline & R1 & $\mathrm{R} 2$ & R3 & $\mathrm{R} 4$ & \\
\hline DMI (kg) & 1.40 & 1.44 & 1.34 & 1.42 & 0.03 \\
\hline Milk yield (kg/h/d) & 1.14 & 1.02 & 1.27 & 1.35 & 0.06 \\
\hline $4 \%$ FCM $(\mathrm{kg} / \mathrm{h} / \mathrm{d})$ & 1.02 & 0.93 & 1.13 & 1.27 & 0.07 \\
\hline \multicolumn{6}{|l|}{ Milk composition, $\%$} \\
\hline Fat & $3.21^{\mathrm{c}}$ & $3.46^{\mathrm{b}}$ & $3.28^{\mathrm{c}}$ & $3.63^{\mathrm{a}}$ & 0.05 \\
\hline Protein & 3.41 & 3.40 & 3.42 & 3.55 & 0.09 \\
\hline Lactose & 3.53 & 3.77 & 3.47 & 3.84 & 0.08 \\
\hline TS & 10.87 & 11.35 & 10.90 & 11.73 & 0.25 \\
\hline SNF & 7.66 & 7.89 & 7.63 & 8.10 & 0.14 \\
\hline Ash & 0.72 & 0.72 & 0.73 & 0.71 & 0.01 \\
\hline Vitamin E (mg/100 g) & $0.12^{\mathrm{b}}$ & $0.13^{\mathrm{b}}$ & $0.24^{\mathrm{a}}$ & $0.28^{\mathrm{a}}$ & 0.02 \\
\hline Selenium (mg/l) & $1.96^{\mathrm{b}}$ & $2.05^{\mathrm{b}}$ & $2.57^{\mathrm{a}}$ & $2.59^{\mathrm{a}}$ & 0.09 \\
\hline Feed efficiency & & & & & \\
\hline Milk yield/DMI, $\mathrm{kg} / \mathrm{kg}$ & $0.81^{\mathrm{ab}}$ & $0.71^{b}$ & $0.95^{\mathrm{a}}$ & $0.95^{\mathrm{a}}$ & 0.04 \\
\hline
\end{tabular}

Feeding on rations contained SFS (R2 and R4) significantly ( $\mathrm{P}<0.05)$ increased milk fat content than that with R1and R3. The same result was mentioned by Zucali et al. (2007) and Morsy et al. (2015). However, Dayani et al. (2004) recorded a decrease in milk fat content. While, Petit et al. (2004) and Abd El-Nabi (2012) reported no change in milk fat content with SFS supplementation. Morsy et al. (2015) explained the increase in milk fat content with SFS as a result of increasing either carbon production in rumen or milk lactose content, whereas Sanz Sampelayo et al. (2002) found high correlation between milk lactose and fat contents $(\mathrm{r}=0.95)$. In the same trend, our study showed an increase in milk lactose content with R2 and R4. The highest fat content was recorded when ration supplemented with SFS and Vit E plus Se (R4) being 3.63\%. In this concern, Bell et al. (2006), Pottier et al. (2006) and Liu et al. (2008) found that supplementation with Vit E plus Se can alleviate the depression in milk fat especially when dairy cows fed high fat rations. There were no significant differences among groups in milk protein, lactose, TS and SNF contents. These results coincide with those obtained by Dayani et al. (2004), Abd ElNabi (2012) and Morsy et al. (2015). The highest TS content was recorded for R2 and R4. This result may be related to the highest fat and lactose contents when goats fed either R2 or R4.

There was a significant $(\mathrm{P}<0.05)$ increase in milk contents of Vit. $\mathrm{E}$ and selenium by $(100$ and $31 \%)$ and (133 and 32\%), respectively with R3 and R4 compared with R1, while, feeding on R2 wasn't significantly $(\mathrm{P}<0.05)$ different than that of R1. Charmley et al. (1993) showed that combination of Vit $\mathrm{E}(8000 \mathrm{IU} / \mathrm{d})$ and Se $(5 \mathrm{mg} / \mathrm{d})$ increased milk concentrations of Vit E (from 0.92 to $1.75 \mu \mathrm{g} / \mathrm{ml}$ ) and Se (from 14.3 to $34.6 \mu \mathrm{g} / \mathrm{l}$ ). Also, Liu et al. (2008) found that milk Vit E and Se were increased by 45 and $142 \%$, respectively when the two antioxidants added together $(0.3 \mathrm{mg} \mathrm{Se} / \mathrm{kg} \mathrm{DM}$ and $10,000 \mathrm{IU} / \mathrm{d}$ vitamin E) to cows ration. Knowles et al. (1999) and Juniper et al. (2006) mentioned that supplementation of dairy cows ration with selenized yeast increased milk Se concentration. Focant et al. (1998) recorded an increase in milk Vit E (from 1.30 to $2.67 \mathrm{mg} / \mathrm{kg}$ milk) when lactating dairy cows ration was supplemented with oilseeds (rapeseed and linseed) plus Vit E. 
Data in the same Table indicated that goats fed on R3 and R4 had the highest feed efficiency which may be related to the increase in milk production. The decrease in feed efficiency with $\mathrm{R} 2$ may be due to the decrease in milk yield. While, SFS supplementation had no significant effect on feed efficiency in other studies (Beauchemin et al., 2009 and Morsy et al., 2015).

\section{Milk fatty acids profile:}

Data concerning milk fatty acids profile (Table 5) indicate that total saturated fatty acids (TSFA) decreased and total unsaturated fatty acids (TUFA), mono- (MUFA) and poly-unsaturated fatty acids (PUFA) increased with SFS supplementation (R2 and R4). The same results were obtained by Petit et al. (2004), Zucali et al. (2007) and Morsy et al. (2015) with rations supplemented with SFS. Ruminants cannot synthesis poly-unsaturated fatty acids, therefore this result could be related to the high content of unsaturated fatty acids in SFS. Abd El-Nabi (2012) explained the high TUFA and low TSFA concentrations with feeding SFS ration by the natural protection of oil seed hulls which facilitate oil intact by-passing from the rumen. Markus et al. (1996) found that supplementation of SFS decreased short chain fatty acids and increased long chain fatty acids.

In this study, data indicated that there were increase in long chain fatty acids especially C18:1, C18:2 and C18:3 and decrease in short chain fatty acids such as C12:0, C14:0 and C16:0. These results are in agreement with the findings of Parodi (2009) that saturated fatty acids such as C8:0, C10:0 and C18:0 might have no role in cardiovascular disease, while saturated fatty acids such as C12:0, C14:0 and C16:0 considered as cholesterol-raising factors. Concentrations of medium chain fatty acids (C14:0 - C17:0) were decreased with R2 and R4 being 38.00 and 32.77 compared to $44.42 \mathrm{~g}$ in control (R1). Grummer (1991) and Dhiman et al. (2000) suggested that the increase in long chain fatty acids may inhibit the de novo synthesis of medium chain fatty acids in the mammary gland.

Table (5): Effect of experimental rations on milk fatty acids profile.

\begin{tabular}{|c|c|c|c|c|c|}
\hline \multirow{2}{*}{ Item } & \multicolumn{4}{|c|}{ Experimental rations } & \multirow{2}{*}{$\pm \mathrm{SE}$} \\
\hline & $\mathrm{R} 1$ & $\mathrm{R} 2$ & R3 & $\mathrm{R} 4$ & \\
\hline Fatty acids \%: & & & & & \\
\hline $\mathrm{C} 8: 0$ & $1.65^{\mathrm{d}}$ & $2.24^{\mathrm{b}}$ & $1.97^{\mathrm{c}}$ & $3.65^{\mathrm{a}}$ & 0.23 \\
\hline C10:0 & $7.65^{\mathrm{c}}$ & $8.35^{\mathrm{b}}$ & $7.51^{\mathrm{d}}$ & $11.09^{\mathrm{a}}$ & 0.43 \\
\hline C12:0 & $3.93^{\mathrm{a}}$ & $3.32^{\mathrm{c}}$ & $3.47^{\mathrm{b}}$ & $2.95^{\mathrm{d}}$ & 0.11 \\
\hline C13:0 & $0.37^{\mathrm{c}}$ & $0.31^{\mathrm{c}}$ & $1.11^{\mathrm{a}}$ & $0.54^{\mathrm{b}}$ & 0.09 \\
\hline C14:0 & $9.21^{\mathrm{a}}$ & $8.31^{\mathrm{b}}$ & $9.16^{\mathrm{a}}$ & $7.93^{\mathrm{c}}$ & 0.17 \\
\hline $\mathrm{C} 14: 1$ & $0.80^{\mathrm{c}}$ & $0.92^{\mathrm{b}}$ & $0.86^{\mathrm{bc}}$ & $1.06^{\mathrm{a}}$ & 0.03 \\
\hline C15:0 & $1.62^{\mathrm{a}}$ & $1.47^{\mathrm{a}}$ & $1.31^{\mathrm{b}}$ & $1.47^{\mathrm{a}}$ & 0.04 \\
\hline C16:0 & $31.57^{\mathrm{a}}$ & $25.72^{\mathrm{b}}$ & $31.30^{\mathrm{a}}$ & $21.52^{c}$ & 1.31 \\
\hline C16:1 & $0.13^{\mathrm{d}}$ & $0.52^{\mathrm{b}}$ & $0.20^{\mathrm{c}}$ & $0.69^{\mathrm{a}}$ & 0.07 \\
\hline C17:0 & 1.09 & 1.06 & 1.07 & 0.10 & 0.02 \\
\hline C18:0 & $22.69^{\mathrm{a}}$ & $19.90^{\mathrm{ab}}$ & $22.18^{\mathrm{ab}}$ & $19.71 b$ & 0.54 \\
\hline C18:1 & $17.98 \mathrm{~b}$ & $24.29^{\mathrm{a}}$ & $18.16^{\mathrm{b}}$ & $24.81^{\mathrm{a}}$ & 1.04 \\
\hline C18:2 & $0.22^{\mathrm{c}}$ & $1.17^{\mathrm{a}}$ & $0.41^{\mathrm{b}}$ & $1.20^{\mathrm{a}}$ & 0.13 \\
\hline C18:3 & $1.11^{\mathrm{b}}$ & $2.29^{\mathrm{a}}$ & $1.29^{\mathrm{b}}$ & $2.52^{\mathrm{a}}$ & 0.19 \\
\hline TSFA & $79.77^{\mathrm{a}}$ & $70.80^{\mathrm{b}}$ & $79.07^{\mathrm{a}}$ & $69.97^{\mathrm{b}}$ & 1.43 \\
\hline TUFA & $20.23^{b}$ & $29.19^{\mathrm{a}}$ & $20.93^{\mathrm{b}}$ & $30.03^{\mathrm{a}}$ & 1.40 \\
\hline MUFA & $18.90^{\mathrm{b}}$ & $25.73^{\mathrm{a}}$ & $19.23^{b}$ & $26.55^{\mathrm{a}}$ & 1.09 \\
\hline PUFA & $1.33^{\mathrm{c}}$ & $3.46^{\mathrm{a}}$ & $1.70^{\mathrm{b}}$ & $3.48^{\mathrm{a}}$ & 0.30 \\
\hline
\end{tabular}

$a, b, \ldots . .$. Means in the same row with different superscripts are significantly different $(P<0.05)$

TSFA: total saturated fatty acids, TUFA: total unsaturated fatty acids, MUFA: mono- unsaturated fatty acids, PUFA: poly- unsaturated fatty acids.

Regarding Vit E and Se supplementation, R3 had the same trend compared with R1 in most of FA concentrations. However, R3 showed a significant $(\mathrm{P}<0.05)$ increase in PUFA and insignificant improvement in MUFA compared with R1. Liu et al. (2008) found that supplementation with Vit E and Se increased TUFA and decreased TSFA in cow milk and explained these results by the ability of Vit E and Se as two antioxidants in inhibiting the oxidation of unsaturated FA more than saturated FA. It was observed that when Vit E added to ration supplemented either with oilseeds such as rapeseed and linseed (Focant et al., 1998) or with safflower and flaxseed oils (Bell et al., 2006) decreased saturated FA and increased unsaturated FA. 


\section{CONCLUSION}

It could be summarized that combination of whole sunflower seeds to provide $3.5 \%$ oil and vitamin $\mathrm{E}$ $(250 \mathrm{IU} / \mathrm{h} / \mathrm{d})$ plus selenium $(2 \mathrm{mg} / \mathrm{h} / \mathrm{d})$ in lactating Baladi goats' ration increased nutrients digestibility, milk production and milk fat content. Moreover, total unsaturated fatty acids and poly- unsaturated fatty acids were increased, while total saturated fatty acids were decreased in milk which could positively affect consumer's health.

\section{REFERENCES}

Abd El-Nabi, H.A.S. (2012). Impact of different forms of oils on lactation performance and conjugatedlinoleic acid content in goat milk. Ph.D. Thesis, Fac. Agric., Cairo Univ., Egypt, 80 p.

AOAC (1995). Official Methods of Analysis of AOAC International, 16th Ed. Vol.1, "Agricultural, Chemicals, Contaminants, Drugs". Washington, D.C., USA, 521p.

AOAC (2012). Official Methods of Analysis of AOAC International, 19th Ed. Vol.1, "Animal feed". Maryland, USA, chapter 4:1-77.

Bayril, A.; A.S. Yildiz; F. Akdemir; C. Yalcin1; M. Köse and O. Yilmaz (2015). The technical and financial effects of parenteral supplementation with selenium and vitamin E during late pregnancy and the early lactation period on the productivity of dairy cattle. Asian Australas. J. Anim. Sci., 28: 11331139.

Beauchemin, K.A.; S.M. McGinn; C. Benchaar and L. Holtshausen (2009). Crushed sunflower, flax, or canola seeds in lactating dairy cow diets: Effects on methane production, rumen fermentation, and milk production. J. Dairy Sci., 92: 2118-2127.

Bell, J.A.; J.M. Griinari and J.J. Kennelly (2006). Effect of safflower oil, flaxseed oil, monensin, and vitamin $\mathrm{E}$ on concentration of conjugated linoleic acid in bovine milk fat. J. Dairy Sci., 89: 733-748.

Charmley, E.; J.W.G. Nicholson and J.A. Zee (1993). Effect of supplemental vitamin E and selenium in the diet on vitamin $\mathrm{E}$ and selenium levels and control of oxidized flavor in milk from Holstein cows. Can. J. Anim. Sci., 73: 453-457.

Danish Official (1996). National food agency of Denmark for vitamin E. $3^{\text {rd }}$ ed. HPLC method No. AF 225.1 .

Dayani, O.; G. Ghorbani; T. Entz; C.M. Ross; M.A. Shah; K.A. Beauchemin; P. S. Mir and Z. Mir (2004).Effect of dietary soybean or sunflower seeds on milk production, milk fatty acid profile and yield of conjugated linoleic acid. Can. J. Anim. Sci., 84: 113-124.

Dhiman, T. R.; L.D. Satter; M.W. Pariza; M.P. Galli; K. Albright and M. X. Tolosa (2000). Conjugated linoleic acid content of milk from cows offered diets rich in linoleic and linolenic acid. J. Dairy Sci., 83: 1016-1027.

Doumas, B.; W. Wabson and H. Biggs (1971). Albumin standards and measurements of serum with bromochresol green. Clin. Chem. Acto., 31:87.

Doyon, M and J. Labrecque (2008). Functional foods: a conceptual definition. British Food Journal, 110: 1133-1149.

Duncan, D.B. (1955). Multiple range and multiple F tests. Biometrics, 11: 1-42.

Ebrahimi, M.; M.A. Rajion and Y.M. Goh (2014). Effects of oils rich in linoleic and $\alpha$-linolenic acids on fatty acid profile and gene expression in goat meat. Nutrients, 6: 3913-3928.

Ekeren, P.A.; D.R. Smith; D.K. Lunt and S.B. Smith (1992). Ruminal biohydrogentation of fatty acids from high oleate sunflower seeds. J. Anim. Sci., 70: 2574-2580. 
Farag, R.S.; S.A.S. Hallabo; F.M. Hewedi and A.E. Basyony (1986). Chemical evaluation of rape seed. Fette-Seifen, Anstrichmittel, 88: 391-397.

Flegg, H.M. (1973). Cholesterol colorimetric method. Ann. Clin. Biochem., 10: 79.

Focant, M.; E. Mignolet; M. Marique; F.Clabots; T. Breyne and Y. Larondelle (1998). The effect of vitamin $\mathrm{E}$ supplementation of cow diets containing rapeseed and linseed on the prevention of milk fat oxidation. J. Dairy Sci., 81: 1095-1101.

Garcia-Bojalil, C.M.; C.R. Staples; C.A. Risco; J.D. Savio and W.W. Thatcher (1998). Protein degradability and calcium salts of long-chain fatty acids in the diets of lactating dairy cows: Productive responses. J. Dairy Sci., 81: 1374-1384.

Grummer, R.R. (1991). Effect of feed on the composition of milk fat. J. Dairy Sci., 74: 3244-3257.

Jenkins, T.C. and D.L. Palmquist (1982). Effect of added fat and calcium on in vitro formation of insoluble fatty acids soaps and cell wall digestibility. J. Anim. Sci., 55: 957-963.

Juniper,D.T.; R.H. Phipps; A.K. Jones and G. Bertin (2006). Selenium supplementation of lactating dairy cows: Effect on selenium concentration in blood, milk, urine and feces. J. Dairy Sci., 89: 3544-3551.

Kim, H.S.; J.M. Lee; S.B. Park; S.G. Jeong; J.K. Jung and K.S. Im (1997). Effect of vitamin E and selenium administration on the reproductive performance in dairy cows. Asian-Aust. J. Anim. Sci., 10: 308-312.

Knowles, S.O.; N.D. Grace; K. Wurms and J. Lee (1999). Significance of amount and form of dietary selenium on blood, milk, and casein selenium concentrations in grazing cows. J. Dairy Sci., 82: 429437.

Kralik, G.; G.Kušec; M.Grčević; I. Đurkin and I. Kralik (2012). Animal products as conventional and functional food-An overview. 20th Int. Symp. “Animal Science Days” , Kranjska gora, Slovenia, Sept. 19th-21st, 2012.

Lacetera, N.; U. Bernabuci; B. Ronchi and A. Nardone (1996). Effects of selenium and vitamin E administration during a late stage of pregnancy on colostrum and milk production in dairy cows, and on passive immunity and growth of their offspring. Am. J. Vet. Res., 57: 1776-1780.

Latorre, A.O.; G.F. Greghi; A.S. Netto; H. Fukumasu; J.C. Balieiro L.B. Côrrea and M.A. Zanetti (2014). Selenium and vitamin E enriched diet increases NK cell cytotoxicity in cattle. Pesq. Vet. Bras., 34: 1141-1145.

Liu, Z.L.; D.P. Yang; P. Chen; W.X. Dong and D.M. Wang (2008). Supplementation with selenium and vitamin $\mathrm{E}$ improves milk fat depression and fatty acid composition in dairy cows fed fat diet. AsianAust. J. Anim. Sci., 21: 838-844.

Margaret, P.R. (2000). The importance of selenium to human health. The Lancet, 356: 233-241.

Markus, S.B.; K.M. Wittenberg; J.R. Ingalls and M. Undi (1996). Production responses by early lactation cows to whole sunflower seed or tallow supplementation of a diet based on barley. J. Dairy Sci., 79: 1817-1825.

Merck (2014). The Merck Veterinary Manual. http://www. merckmanuals.com/vet/appendixes/reference_guides/serum_biochemical_reference_ranges.html.

Mohammed, R.; S. M. McGinn and K. A. Beauchemin (2011). Prediction of enteric methane output from milk fatty acid concentrations and rumen fermentation parameters in dairy cows fed sunflower, flax, or canola seeds. J. Dairy Sci., 94: 6057-6068.

Morsy, T.A.; S.M. Kholif; A.E. Kholif; O.H. Matloup; A. Z. M. Salem and A. Abu Elella (2015). Influence of sunflower whole seeds or oil on ruminal fermentation, milk production, composition and fatty acid profile in lactating goats. Asian Australas. J. Anim. Sci. 28: 1116-1122.

Muniz-Naveiro, O.; R.Dominiquez-Gonzalez; A. Bermejo-Barrera; J.A. Cocho; J.M. Fraga and P. Bermejo-Barrera (2005). Determination of total selenium and distribution in the milk phases in commercial cow's milk by HG-AAS. Analytical and Bioanalytical Chemsistry, 381: 1145-1151. 


\section{Ghoneem}

Narimani-Rad, M.; H.A. Shahryar; M.K. Nahand and A. Lotfi (2012). Effect of sunflower oil supplementation on in vitro fermentation patterns of forage based diets for ruminant. Bull. Env. Pharmacol. Life Scien., 1: 73- 77.

NRC, (1981). Nutrient requirements of goats: angora, dairy and meat goats in temperate and tropical countries. Washington, D.C. National Academy Press (eds.).

Parodi, P.W. (2009). Review: has the association between saturated fatty acids, serum cholesterol and coronary heart disease been over emphasized? Int. Dairy J., 19: 345-361.

Petit, H.V.; C. Germiquet and D. Lebel (2004). Effect of feeding whole, unprocessed sunflower seeds and flaxseed on milk production, milk composition and prostaglandin secretion in dairy cow. J. Dairy Sci., 87: 3889-3898.

Pfister, J.A.; T.Z. Davis and J.O. Hall (2013). Effect of selenium concentration on feed preferences by cattle and sheep. J. Anim. Sci., 91: 5970-5980.

Pizzoferrato, L.; P. Manzi; S. Marconi; V. Fedele; S. Claps and R. Rubino (2007). Degree of antioxidant protection: A parameter to trace the origin and quality of goat's milk and cheese. J. Dairy Sci., 90: 4569-4574.

Pottier, J.; M. Focant; C. Debier; G. De Buysser; C. Goffe; E. Mignolet; E. Froidmont and Y. Larondelle (2006). Effect of dietary vitamin $\mathrm{E}$ on rumen biohydrogenation pathways and milk fat depression in dairy cows fed high-fat diets. J. Dairy Sci., 89: 685-692.

Sanz Sampelayo, M.R.; L. Pérez; J.J. Martin Alonso; L. Amigo and J. Boza (2002). Effects of concentrates with different contents of protected fat rich in PUFAs on the performance lactating Granadina goats. Part II. Milk production and composition. Small Rumin. Res., 43:141-148.

SAS (2009). Statistical Analysis System. User's Guide: Statistics. Version 9.2.SAS Inst. Inc., Cary, NC., USA. pp. 7869.

Smeti, S.; H. Hajji; K. Bouzid; J. Abdelmoula; F. Muñoz; M. Mahouachi and N. Atti (2014). Effects of Rosmarinus officinalis $L$. as essential oils or in form of leaves supplementation on goat's production and metabolic statute. Trop. Anim. Health Prod., 47: 451-457.

Snedecor, G.W. and W.G.Cochran (1982). Statistical Methods.7th ed. Iowa State Unvi. Press, Ames, Iowa, USA, 213p.

Steel, R.G.D. and J.H.Torrie (1980). Principles and procedures of statistical analysis.2nd ed. Mc GrowHill; London.

Tietz, N.W. (1990). Clinical Guide to Laboratory Tests 2nd Ed. Philadelphia.

Van-Keulen, J. and B.A. Young (1977). Evaluation of acid-insoluble ash as a natural marker in ruminant digestibility studies. J. Anim. Sci., 44:282-310.

Vargas J.E.; S. Andrés; D.R. Yáñez Ruiz and S. López (2011). The effect of olive, sunflower or linseed oils on the fermentation pattern and methane production in the rumen simulating technique, Options Méditerranéennes, 99: 163-168.

Young, D.S. (1990). Effects of drugs on clinical laboratory tests, 3rd Ed. Washington, D.C., AACC Press, pp. 232.

Zanetti, M.A.; L.B.Correa; A. Saran Netto; J.A.Cunha; R.S.S.Santana and S.M.F.Cozzolino (2015). Influence of canola oil, vitamin $\mathrm{E}$ and selenium on cattle meat quality and its effects on nutrition and health of humans. Proceedings of the 4th International Conference on Selenium in the Environment and Human Health, 18-21 October 2015 in São Paulo, Brazil.

Zucali, M.; B. Luciana; C. Penati and L. Rapetti (2007). Effect of raw sunflower seeds on goat milk production in different farming systems. Ital. J. Anim. Sci., 6(suppl. 1): 633-635. 
تأثير اضافة بذور عباد الشمس مع أو فيتامين هـ والسلينيوم على تركيب اللبن والاحماض الدهنية للماعز البلاى

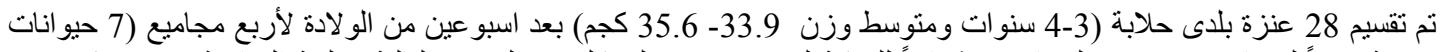

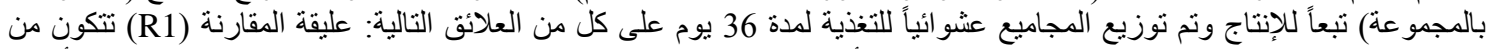

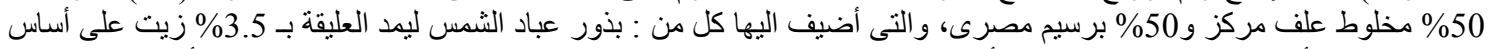

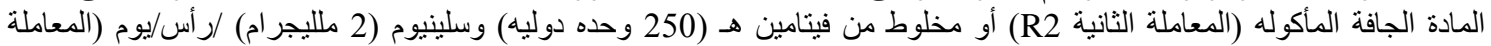

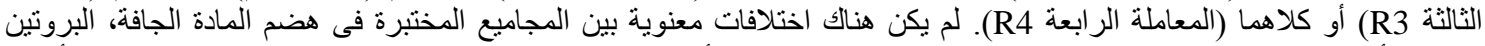

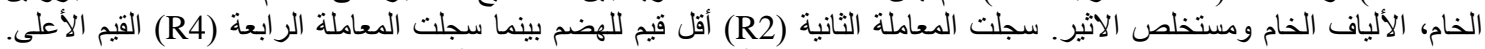

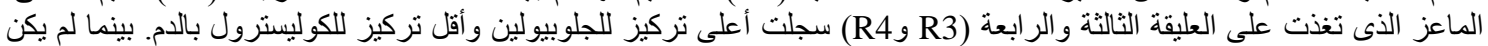

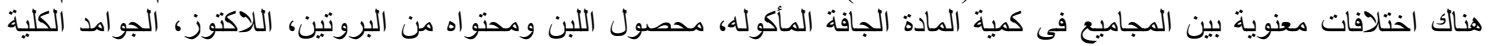

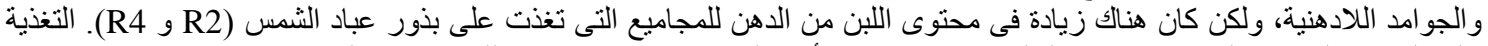

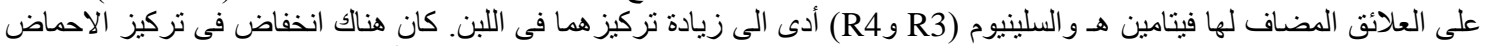

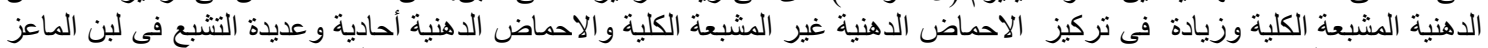

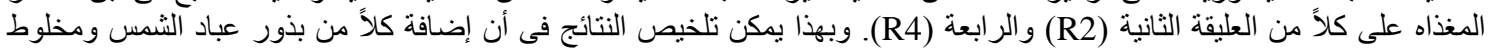

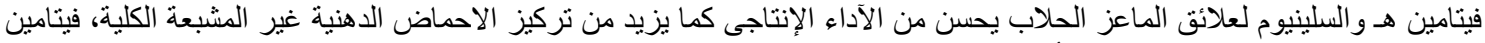
هـ و السلينيوم في اللبن مما قد يكون له تأثير جيد على صحة المستهلكين. 